\title{
Discussion on the Optimization of UG CAM Teaching Method
}

\author{
Pingqing Fan*, Bo Zhao \\ School of Mechanical and Automotive Engineering, Shanghai University of Engineering Science, Shanghai, China \\ Email: ^fanpingqing@163.com
}

How to cite this paper: Fan, P.Q. and Zhao, B. (2019) Discussion on the Optimization of UG CAM Teaching Method. Open Access Library Journal, 6: e5284. https://doi.org/10.4236/oalib.1105284

Received: February 22, 2019

Accepted: March 17, 2019

Published: March 20, 2019

Copyright (C) 2019 by author(s) and Open Access Library Inc.

This work is licensed under the Creative Commons Attribution International License (CC BY 4.0).

http://creativecommons.org/licenses/by/4.0/

\begin{abstract}
According to the present teaching situation of UG CAM course, this paper probes into the practical teaching method of UG CAM course, so that the students can master the principles and methods of computer-aided manufacturing in the course of practical operation. To enable students to use UG CAM knowledge to simulate the processing of automotive parts, so as to obtain the ability of applying theoretical knowledge to solve practical problem. Computer-assisted (CAM) can make students participate in teaching activities actively, fully reflect students' main position, cultivate students' ability of active learning, and combine theory with practice. At the same time, it can also improve the quality and effect of UG teaching, so that it can be used for practical use.
\end{abstract}

\section{Subject Areas \\ Computer Engineering, Education}

\section{Keywords}

Excellent Engineer, Practice Teaching, UG CAM

\section{Introduction}

UGII is an representative numerical control software in the industry. UG/CAM provides a single processing solution from drilling, and wire cutting to 5 axis milling [1]. The model, process, optimization and tool management in the machining process can be connected with the main model design and maintain the highest production efficiency. By combining the customization ability of UG extension with the ability of process capture, the correct processing scheme can be obtained at one time [2] [3].

UG CAM course is a highly technical, practical and professional skill identifi- 
cation course, which has strong application and practicability. Students are trained to program parts NC machining with UG software [4]. The operation ability of NC machining and the improvement of students' practical ability and engineering ability are in line with the training requirements of the excellent plan. To achieve the ideal teaching effect, there should be good practical teaching methods and practical teaching methods. The practical teaching of the course is of great significance to the improvement of the quality of the training of talents in numerical control technology and the employment ability and quality of graduates [5].

\section{Practice Teaching Requirements of UG CAM}

UG CAM, as a special elective course of vehicle engineering, is aimed at mastering the principle and method of computer-aided manufacturing, so that students can master the basic knowledge of CAM and the method of using it. And to obtain the application of theoretical knowledge to solve practical problems of the initial ability; Master the setting of UG CAM machining environment, tool, method and geometry parent node group, set up common options, master the programming methods of plane milling, cavity milling, contour milling of fixed axis curved surface, etc.

In the course of daily teaching, this class focuses on the basic machining modules of UG CAM, including the transformation of machining environment, the establishment and modification of coordinates and cutters, the establishment of operating navigators and various parent nodes, plane milling, surface milling and cavity milling. Visual verification and output of tool path, point machining and lettering, and the application of WAVE technology in machining are introduced. It also includes the concepts of various CAM libraries and the main editing methods used in machining operations, including tool library, machine tool library, material library, cutting method library, feed speed and spindle speed library, etc.

Through the study of this course, students are required to have the ability of NC programming and machining of common parts, especially automobile parts, and can solve the problems in actual production. UG software is a set of CAD\&CAM software. CAE function in an integrated system, the study of this course for the follow-up of CAD/CAM/CAE integration education among college students laid the foundation.

\section{UG CAM Teaching Method}

Students thinking flexible, and 3D space imagination is strong, in the practical ability to continue to strengthen. In view of these problems, the following methods are mainly used in practical teaching to give full play to the students' advantages, to improve the students' practical ability and to solve the practical problems [6] [7].

The teaching organization form of the integration of theory and practice: 
In the teaching, we adopt the teaching organization form of integrating theory and practice, combine theory with practice organically, synchronize theory teaching and skill training, emphasize theory guiding practice, prove theory knowledge through practice; to enable students to think, pay attention to practice, pay attention to the cultivation of knowledge application ability.

To give full play to the student's subjective initiative: In practical practice, teachers and students complete the teaching process by teaching, learning and doing, so that students can find problems, think about problems, analyze problems and solve problems in the process of practice, so as to fully mobilize students' enthusiasm and initiative.

Pay attention to the consistency of practice and practical work: This class simulates the atmosphere and situation of the working process of product design and manufacture in enterprises, and takes automobile parts as the project carrier to make students familiar with the use of software in the process of teaching and practice. Cultivate students' innovative consciousness and further improve students' innovative ability.

Adopt the teaching mode of combining work and study: The teaching goal is realized through the combination of work and study which is closely related to the professional posts, the teaching process is closely combined with the practical training of the training base inside and outside the school, and the practice of industry-university-research, etc., which creates good practice opportunities for the students.

The combination of in-class teaching and extracurricular second class: Fully tap and utilize the second class of students: all kinds of innovation groups, open laboratories, enterprises sign up teaching experimental base, participate in teacher's research, encourage students to participate in Honda racing, FSAE racing, apply for college students' innovation plan, etc. Apply the lessons learned in class to practice and improve students' ability to bear and solve problems.

Case study: Due to the strong practicality of UG CAM, the practice should be closely related to the teaching process. At the same time, we must strengthen the practice of curriculum practice and curriculum design. At present, although the practical practice can meet the teaching requirements, it is not systematic enough. Some examples introduced in the book are out of touch with practical production. The case analysis of typical automobile parts is introduced, such as engine connecting rod, body machining, ribbed plate machining and so on in order to summarize the method of knowledge application in practice.

Certificate education: To encourage students to participate in authoritative certification of the qualification examination, improve the employability of students. To encourage students to take the qualification examinations of some authoritative institutions, not only to study because of the examination, but also to find new and higher goals for students, so that students can understand the demand for professional engineering design personnel in the field of social industry. At the same time, it also improves students' interest in autonomous learning, promotes the quality of curriculum teaching, and promotes students' employa- 
bility and competitiveness.

Construction of the course website: Make full use of the good network environment and abundant network digital teaching resources, through the construction of this course, the network course will be realized. The online resources include the brief introduction of the teacher, the course group, the teaching method, the teaching outline, teaching plan, multimedia courseware, animation demonstration of practical practice, homework exercises, references and so on. Easy for students to use network resources, self-study after school time, deepen understanding, strengthen learning.

Multimedia classrooms: The role of modern teaching means such as multimedia is full play in teaching. The PPT courseware and the animation demonstration produced by the teaching resources are applied to the teaching, and the combination of the text and the image and the static and dynamic combination can stimulate the interest of the students and improve the teaching effect.

In-school training equipment and training environment: All the teaching activities are arranged in the CAD/CAM laboratory. In the laboratory, each student has a high grade computer with a 17 inch liquid crystal display. Teachers can ask questions and practice each other at any time through multimedia software, and have a large number of technical design drawings. The digital information such as structural 3D model can be used and output drawings and post-processing files at any time, and a practical task can be completed at any time according to requirements, which can meet the needs of course simulation and training.

In the institute's modern manufacturing training center, there are various $\mathrm{CNC}$ machine tools, machining centers, and other numerical control processing equipment. Here, students can use the data from the previous work to operate the NC equipment for processing. In order to meet the needs of course completion from simulation to production training, training equipment and facilities are also fully utilized.

\section{Conclusion}

Through the exploration and practice of the practical teaching method of "UG CAM", good teaching effect has been obtained. Students learn in practice, grow in practice, have certain engineering ability and innovation ability, dare to solve, and can solve some problems of simulation processing in actual production.

\section{Acknowledgements}

This work is supported by the Shanghai municipal education commission key curriculum construction project (Grant No. A1-0601-18-01009).

\section{Conflicts of Interest}

The authors declare no conflicts of interest regarding the publication of this paper. 


\section{References}

[1] Zhang, D.H. and Guo, Y. (2011) The Optimal Design of the Course Content of the Die Course Based on the Production Process. Vocational Education Research, No. 4, 104-105.

[2] Lin, J. (2011) A Study on the Specialty training Program of "Education and Training Program for Outstanding Engineers". The Educational Research of Tsinghua University, 32, 47-55.

[3] Lin, C.D. (2010) The Characteristics of Creative Talents and the Reconstruction of Educational Model. Chinese Journal of Education, No. 6, 1-4.

[4] Zhang, A.F. and Liu, X.F. (2010) Reflections on the Implementation of the "Education and Training Plan for Outstanding Engineers". Research on Higher Engineering Education, No. 4, 56-59.

[5] Zhang, J.X. and Chen, G.T. (2010) A Probe into the Talent Training Model of Engineering Colleges and Universities under the Background of "Excellence Plan". Construction Education in China, 5, 4-7.

[6] Zeng, Y.W. and Liu, G.R. (2011) A Probe into the Scientific Construction of Practical Teaching System under the Background of "Excellence Plan". University Teaching in China, No. 7, 75-78.

[7] Lei, F. (2012) Problems and Policies in the Course of UG CAM. Mechanical Vocational Education, 10, 52-53. 